\title{
Structures of Trust after Stalin
}

\section{YORAM GORLIZKI}

TRUST is a tantalizing term. Neither easily defined nor observed, it is nonetheless widely used. One of the particular challenges of trust is that the most intellectually compelling definitions of the concept are also the most difficult to pin down empirically. ${ }^{1}$ Those who study trust often have to make compromises. This is all the more so when it comes to studying a closed society, such as the Soviet Union was for most of its existence. With high levels of censorship and the virtual absence of rigorous surveys, Soviet society provided little systematic data of a kind that would normally be used for a study of trust. In this article I suggest that the insights afforded by trust in the Soviet system nonetheless warrant certain methodological compromises. I contend that understandings of 'trust' and 'distrust' provide a perspective on the changing nature of political relationships that might not otherwise be apparent from a straightforward examination of the sources. My focus will be one particular phase of Soviet history, the cusp of the late Stalin and early post-Stalin eras, when a change in the basis

Yoram Gorlizki is Professor of Politics in the School of Social Sciences at the University of Manchester.

Research for this article was supported by a grant from the UK Economic and Social Research Council (RES-0oo23088o; <http://www.socialsciences.manchester.ac.uk/ sovietprovinces $>$ ). Earlier versions of this article were presented at the Hoover Soviet Archives Workshop at Stanford, the UCL SSEES Conference, 'Trust and Distrust in the Soviet Union', and workshops at Harvard and the University of Pennsylvania. My thanks go to the organizers of these events, Paul Gregory, Geoffrey Hosking, Terry Martin, Kelly O'Neil and Ben Nathans, as well as to the participants, for their advice and comments.

1 I have in mind cognitive accounts according to which trust consists of the truster's assessment of the intentions and competence of the trusted. Hard to verify empirically, such definitions often rely on experimental methods for their testing and development. For the cognitive approach, see Russell Hardin, Trust and Distrust, New York, 2002, pp. $\mathrm{xx}, 7,10-11$. For experimental applications, see Elinor Ostrom and James Walker (eds), Trust and Reciprocity: Interdisciplinary Lessons from Experimental Research, New York, 2003, and Karen S. Cook, Margaret Levi and Russell Hardin (eds), Whom can we Trust? How Groups, Networks, and Institutions Make Trust Possible, New York, 2009, chapters 1-4. 
of trust among political leaders was, I argue, indicative of an underlying transformation of political practices.

The application of trust to the Soviet system is occasioned in part by a broader development in our understanding of the concept of trust. Over the last two decades there has been a discernible shift in the treatment of trust across the humanities and social sciences, one aspect of which concerns the relationship between trust and coercion. Not long ago trust theorists were keen to emphasize the importance of freedom and choice in trust and to demonstrate that trust was, at some level, incompatible with coercion. In a seminal article on trust, Diego Gambetta, for example, paraphrased trust as a 'device for coping with the freedom of others' and placed coercion in a class of activities (along with promises, commitments and contracts) which tries 'to overcome the problem of trust' by placing severe limits on the options available to one's partner. ${ }^{2}$ In the Soviet Union, especially under Stalin, coercion was widespread and most people's freedom was highly circumscribed; as such, the country did not seem particularly well suited to the study of trust. However, recently there has been a reappraisal of the relationship between trust and coercion. For a start, some scholars have begun to identify elements of trust in asymmetric power relationships. ${ }^{3}$ Others have examined the notion of 'forced trust', the idea that certain kinds of trust within communities can emerge in response to coercion from the outside. ${ }^{4}$ Most recently, a new and innovative genre of research has suggested that some of the most interesting forms of trust can emerge precisely in environments marked by very high levels of coercion, such as the criminal underworld. ${ }^{5}$

2 Diego Gambetta, 'Should we Trust Trust?', in Diego Gambetta (ed.), Trust: Making and Breaking Cooperative Relations, Oxford, 1988, pp. 213-37 (pp. 219-20). Gambetta's felicitous phrase on trust and freedom draws on John Dunn, 'Trust and Political Agency', in ibid., pp. 73-93 (p. 73), and on Niklas Luhmann, Trust and Power, Chichester, 1979. Similarly, for Keith Hart, trust emerged out of a 'zone of free floating relationships [between kinship and contract] formed by choice in the expectation of mutuality'. Both etymologically and historically, trust is thus most closely associated with friendship, for a friend is 'someone to whom one is not bound, and hence etymologically speaking free, based on choice not status obligation'. See Keith Hart, 'Kinship, Contract, and Trust: The Economic Organization of Migrants in African City Slum', in Gambetta, Trust, pp. 176-93 (pp. 178, 187 [italics mine]).

3 See in particular Henry Farrell, 'Trust, Distrust, and Power', in Russell Hardin (ed.), Distrust, New York, 2004, pp. 85-105; and Karen S. Cook, Russell Hardin and Margaret Levi, Cooperation without Trust?, New York, 2005, pp. 54-55.

4 See, in particular, Alena Ledeneva, 'The Geneaology of Krugovaia Poruka: Forced Trust as a Feature of Russian Political Culture', in Ivana Markova (ed.), Trust and Democratic Transition in Post-Communist Europe, Oxford, 2004, pp. 85-108.

5 See in particular, Diego Gambetta, Codes of the Underworld: How Criminals 
If we are to employ trust as a tool for comparative analysis we need to begin with a benchmark. In this essay trust refers to a reasoned expectation that another person will cooperate in a certain matter in conditions that I cannot anticipate. ${ }^{6}$ For it to count as trust, the grounds for this expectation are important. If I believe that the other person will cooperate simply because their interests are aligned to mine, all I have is an 'expectation' and there is little to be gained from characterizing this as a form of trust. For it to qualify as trust the expectation needs to be rooted in something beyond mere compatibility of interests. Most often trust is grounded in an on-going personal relationship which the parties in the relationship value. Personal relationships often have a number of trust-enhancing features, such as in-depth knowledge of one's partner and the requisite incentives to support trust. The cases of trust examined in this article fall into this category of trust. ${ }^{8}$ Given the undoubted significance of distrust in the Soviet Union under Stalin, the concept of distrust also requires a brief elaboration here. Probably the most important thing to note about distrust is that there is an 'asymmetry' between it and trust, which is to say that distrust is not merely the opposite of trust. ${ }^{9}$ Whereas trust is most often grounded in a personal relationship, one can have distrust that is entirely separate from any particular relationship and that exists 'in principle.' ${ }^{10}$ There is, however, one sense in which distrust may be the direct inverse

Communicate, Princeton, NJ, 2009, chapter 3.

6 Along with other writers on trust I focus on interpersonal trust and discount 'social trust', 'generalized trust' or 'trust in institutions' as forms of 'confidence' or, at best, 'quasitrust'.

7 For a useful discussion, see Russell Hardin, Trust and Trustworthiness, New York, 2002, pp. 4-5, 88 .

8 This approach draws on what, following Hardin (Trust and Trustworthiness), has become widely known as the 'encapsulated interest' theory of trust. On the role of knowledge, incentives and mutuality in this approach, see ibid., pp. 13, 17. Note that I am setting to one side a new genre of trust research on so-called 'group trust' (for example, among co-ethnics), where the two parties to the trust relationship do not necessarily need to know each other. On this, see Cook, Levi, and Hardin, Whom Can We Trust?, chapters 1,2 .

9 Thus, for example, it takes less knowledge to instil distrust than to build trust and the potential losses from someone who is untrustworthy are normally greater than the gains from someone who is trustworthy. On this, see, for example, Cook, Hardin and Levi, Cooperation without Trust?, p. 63.

10 This insight lies at the heart of the 'liberal distrust of government' and some of the 'greatest social inventions in history', such as contract law and the US Constitution which, at some level, 'institutionalize distrust'. For a discussion, see ibid., pp. 71, 80-82, 163. The phrase 'institutionalizing distrust' comes from John Braithwaite, 'Institutionalizing Distrust, Enculturating Trust', in Valerie Braithwaite and Margaret Levi (eds), Trust and Governance, New York, 1998, pp. 343-75. 
of trust. Whereas trust is usually grounded in an ongoing personal relationship, an expression of 'distrust' may be taken as a sign that that relationship has come to an end. If, as we shall see below, that relationship is with Joseph Stalin, then you are in trouble.

If trust is grounded in personal relationships and personal relationships tend by their nature to vary, how can we generalize from particular instances of trust? In order to grasp this we need to examine the relationship between trust and institutions. For all its virtues, there are problems in relying on trust as a platform for cooperation on a large scale. First, where the stakes are high, the threat of ending a relationship - the main device by which trust relationships are enforced - may not be enough to deter a partner from defecting from a joint enterprise. Secondly, if trust is grounded in personal relationships, there are epistemological and time constraints on how many people we can know well enough to trust. ${ }^{11}$ Both problems are typically resolved by institutions, which provide the rules and incentives to deter cheating on larger matters and generate information about the likely behaviour of those beyond a narrow circle. ${ }^{12}$ The relationship between trust and institutions is, however, a complex one. Where institutions exist they may, over time, foster regular interactions among actors which can turn into trust relationships. This is particularly true of institutions which are not fully developed and whose rules are only ambiguously defined. ${ }^{13}$ Recent research suggests that this observation may be particularly pertinent to the Soviet Union in Stalin's last years. Whereas the traditional view was that the upper reaches of the Soviet system in this period were marked by a complete lack of properly functioning institutions, recent work has shown that some institutions, albeit quite rudimentary, did in fact exist. I shall argue that these institutions nurtured relationships of trust and shall refer, somewhat schematically, to the patterns of these relationships as 'structures of trust'. ${ }^{14}$

${ }^{11}$ On both points, see Hardin, Trust and Trustworthiness, pp. 109, 128, 175, 188-89, and Cook, Hardin and Levi, Cooperation without Trust?, pp. 80, 150.

${ }^{12}$ From a large literature, I use the definition of institutions offered by Farrell: 'A set of rules that shape the behaviour of communities of actors by providing individuals with information about the likely social consequences of their actions.' See Henry Farrell, 'Institutions and Midlevel Explanations of Trust', in Cook, Levi, and Hardin (eds), Whom Can We Trust?, pp. 127-48 (quotation at p. 127).

13 Whereas institution-based cooperation involves circumstances that have been anticipated in rules, trust by its nature involves cooperation in circumstances that have not been anticipated. Institutions with a large 'penumbra' - situations in which their rules apply only ambiguously - can open up spaces for trust relationships to emerge. For a lucid discussion, see ibid., pp. 135-36.

${ }^{14}$ Although the notion of 'structures of trust' has not been widely used, the one main 
This article begins by looking at how the terms 'trust' (doverie) and 'distrust' (nedoverie) were used by Soviet political leaders in the last years of Stalin's life. While some theorists of trust haughtily dismiss analysis of the word 'trust' and its translations as a form of 'ordinary-language analysis', I suggest that there are certain benefits to be had from such an approach. ${ }^{15}$ While doverie is not in all cases an exact rendering of 'trust' there is a strong equivalence between the two. ${ }^{16}$ But what is significant here is not so much the occasional trust-based associations that are triggered by doverie and nedoverie, but that the relationships between the two, as well as between doverie and institutions, and between doverie and power, are analysable in terms that are familiar from the Western literature on trust. In the second part of the article I go on to suggest that there is a historical lineage connecting systematic control of those with 'compromised backgrounds' in the late Stalin period with the use of kompromat (discrediting information) and political blackmail in today's Russia, and that this lineage can be traced through the early post-Stalin years. I suggest that the thread that runs through these seemingly disparate activities is most fruitfully analysed through the concept of trust. The article ends by exploring the benefits of using trust as a term in Soviet history and by comparing it with its rivals, most notably 'loyalty' or 'objective loyalty'.

\section{'Political Distrust' in the Late Stalin Period}

Under Stalin it comes more easily to talk of distrust than of trust. One reason for this was the extremely high levels of repression and spying which put most Soviet citizens in a constant state of fear. The overriding role of fear was such that some scholars argue that we need to recalibrate our whole understanding of trust to suit the qualitatively distinct circumstances of

exception (S. N. Eisenstadt and L. Roniger, Patrons, Clients and Friends: Interpersonal Relations and the Structure of Trust in Society, Cambridge, 1984) propounds a view of trust that is quite different from the one advanced here. Specifically, Eisenstadt and Roniger argue that the 'unconditional trust' generated in families and small-scale societies could not automatically be transferred to complex societies based on a division of labour; instead new 'structures of trust' developed which assumed choice-based forms ranging from friendship networks to patron-client relations.

${ }^{15}$ For a sceptical view, see Hardin, Trust and Trustworthiness, pp. 57-58.

16 This should not perhaps be surprising given their common historical root. Trust has its etymological origins in the Latin fides and, in turn, in the ancient Greek word for 'faith' pistis; similarly doverie comes from the Russian vera, which in turn, was used as the Old Church Slavonic biblical translation of the same word, pistis. On the lineage in English, see, for example, Anthony Pagden, 'The Destruction of Trust and its Economic Consequences in the Case of Eighteenth Century Naples', in Gambetta, Trust, pp. 127-41 (pp. 129-31). 
'totalitarian' societies. Rather than a 'single and concrete emotion', fear was a 'generalized attitude in a deep and ethical sense'. Accordingly, 'political trust was not conceived in terms of "calculations of risk" as is the case in western democracies but as opposition to fear and terror ${ }^{17}$ Indeed, one of the defining features of Stalinist society was that the socialization of trust common to most liberal democracies was turned on its head and converted into the 'socialization of distrust'. ${ }^{18}$ According to this view, trust was pushed into the margins, while distrust, resting on mutual fear and suspicion, was everywhere.

There are two problems with this view. First, whatever its flaws, the Soviet state exhibited levels of cooperation that were simply too high for it to be merely written off as a case-study in pervasive or all-encompassing distrust. While some of this cooperation was grounded in institutional incentives, it also often rested on inter-personal trust. ${ }^{19}$ This theme is explored in greater detail below. For the moment I want to focus on a second difficulty with the 'totalitarian' view of trust, and this is that the words doverie and nedoverie tended to be used more narrowly than simply to denote one's opposition to 'fear and terror'. If we confine ourselves to the top leadership circle, it was certainly the case that interpretations of doveriel nedoverie tilted strongly towards emphasizing distrust over trust. Even when they referred to 'trust' (doverie) in their personal communications, senior leaders usually had in mind its opposite, as in the phrases 'loss of trust' or 'withdrawal of trust'. Yet if one looks more closely, it soon becomes apparent that they were often referring to distrust in quite a concrete sense rather than merely as a broad synonym for 'fear and terror'.

In order to grasp how 'trust' and 'distrust' were used in elite circles, we should take note of two points. First, there was a strong discursive overlap between references to top-level party institutions and to the dictator. For senior officials, the 'Politburo' or the 'Central Committee' often stood as code-words for Stalin himself. ${ }^{20}$ Secondly, just as trust was normally

17 Ivana Markova, 'Introduction: Trust/Risk and Trust/Fear', in Markova (ed.), Trust and Democratic Transition, pp. 1-24 (pp. 8, 10).

${ }^{18}$ Patrick Watier and Ivana Markova, 'Trust as a Psychosocial Feeling: Socialization and Totalitarianism', in ibid., pp. 25-46 (pp. 26, 39).

19 Ironically, one trust theorist who characterizes the USSR under Stalin as 'perhaps the greatest deliberate experiment in pervasive distrust' also goes on to argue that another society often thought of as a case study in 'pervasive distrust', Oman, must, on closer examination, have had some elements of trust: 'The Omani must have been able to trust one another in their commercial dealings; otherwise, they could not have been such successful traders.' Hardin, Trust and Trustworthiness, pp. 96-98.

${ }^{20}$ Kiril Stoliarov, Palachi i Zhertvy, Moscow, 1997, p. 64; Yoram Gorlizki and Oleg 
grounded in an ongoing personal relationship, an expression of 'distrust' often spelled the end of that relationship. What this meant was that when political leaders spoke or wrote about individuals losing the 'trust of the Central Committee' or attracting the 'political distrust of the party', this was commonly understood as meaning that a person's relationship with Stalin was either at an end or under severe threat. When Stalin's distrust was confirmed, what invariably followed was expulsion from the ruling circle and political excommunication. ${ }^{21}$ Within the ruling circle, maintaining Stalin's 'trust' - which in effect meant avoiding expressions of distrust - was pivotal to a leader's hopes of survival.

Consider the following example. Immediately after the war, Viacheslav Molotov's position was at a low ebb, partly because of unwonted rumours that Molotov might take over from Stalin as leader of the Soviet Union. The exchange between Molotov and Stalin crystallized around Stalin's 'trust' of Molotov, which enfolded other forms of trust, such as the 'trust of the party':

Your ciphered message is filled with deep distrust toward me, both as a Bolshevik and as a person, which I take as a most serious party warning for all my further work. I shall try through deeds to regain your trust, in which every honest Bolshevik sees not only personal trust, but also the trust of the party, which is dearer to me than my own life. ${ }^{22}$

Losing the battle for Stalin's 'trust' could prove calamitous. While Molotov managed to fend off the break with Stalin, not everyone was so lucky. 'I ask you', wrote a despairing Nikolai Voznesenskii to Stalin on 17 August 1949, 'to show me your trust; to vindicate it, I shall ensure that any work you assign me will receive all the effort and energy I have at my disposal. ${ }^{23}$ Unable to regain the leader's 'trust', Voznesenskii was arrested and the following year he was shot. Even outside the ruling circle, the loss of

Khlevniuk, Cold Peace: Stalin and the Soviet Ruling Circle, 1945-1953, New York, 2004, pp. $61,153-54$.

${ }^{21}$ This form of expulsion should be distinguished from the 'shunning' from small, close communities, which involves the application of sanctions for the violation of communal norms. Here the offence is not against communal norms but against the personal whims of the dictator. Cf. Hardin, Trust and Trustworthiness, p. 184; Cook, Hardin and Levi, Cooperation without Trust, pp. 54, 93.

${ }^{22}$ Gorlizki and Khlevniuk, Cold Peace, p. 23; for the Russian original see, Politbiuro TsK VKP(b) i Sovet Ministrov SSSR 1945-1953, Moscow, 2002, p. 200 (italics mine).

${ }^{23}$ Gorlizki and Khlevniuk, Cold Peace, p. 86; for the Russian original, see Politbiuro TsK $V K P(b)$, p. 293. 
'political trust' - especially in an official resolution - spelt catastrophe for an aspiring politician, because it meant that he was formally being cut off from Stalin and his circle. One of several leaders caught in the fallout from the Leningrad Affair was the First Secretary of the Crimean Obkom, and former head of the Leningrad oblispolkom, N. V. Solov'ev, who was dismissed from his post on 6 August 1949 on the grounds that he was 'not worthy of the political trust of the Central Committee. ${ }^{24}$ As with Voznesenskii, Solov'ev was shot.

The Leningrad Affair was the last time that 'political trust' was used in this way in a formal party resolution. For top-level politicians, however, the phrase 'political distrust' continued to have a powerful resonance. Even a political leader reconciled to the end of his career would do what he could to fight off such a charge. This was the case with Grigorii Arutinov, the First Secretary of the Armenian Central Committee. Before assuming this post in 1937, Arutinov had served for three years as head of the Tblisi gorkom, then under Beria's jurisdiction. At the joint plenum of the Armenian Central Committee and Erevan gorkom on 14-15 July 1953 convened to discuss the Beria Affair, Arutinov declared:

I have presented my request to the Central Committee that I be released as Secretary, since I believe that, following the well-known resolution of the Central Committee that raikom secretaries should not remain in office for over 3-5 years, it is not fitting that I should have stayed on for 16 years as First Secretary of the Armenian Central Committee. I have also requested that not only do I give up my seat on the Central Committee, but that that I depart Armenia altogether. ${ }^{25}$

Unfortunately for Arutinov, the matter did not quite end there. At the meeting of the Armenian Central Committee in November 1953, chaired by the All Union Central Committee Secretary Nikolai Pospelov, Arutinov was accused of having been 'insincere' and of 'double-dealing', and was dismissed on the grounds that he was 'undeserving of political trust'. This appears to have touched a raw nerve in Arutinov. On 2 December he penned the following appeal to Molotov:

They charge me with having been nominated by Beria. I honestly say that I never knew of this and only found out about it from Khrushchev after

${ }^{24}$ TsK VKP(b) i regional'nye partiinye komitety 1945-1953, Moscow, 2004, pp. 192, 393.

25 Rossiiskii Gosudarstvennyi Arkhiv Sotsial'no-Politicheskoi Istorii (hereafter, RGASPI) f. 82, op. 2, d. 148, 1l. 32-33. 
the September [1953] plenum [...]. I freely admit that [Beria's] endorsement has undermined my authority as Secretary of the [Armenian] Central Committee and I have no problem in being freed from my post. But how can one, on the basis of this [...] charge me with political distrust? ${ }^{26}$

Arutinov went on to claim that since becoming First Secretary of the Armenian Central Committee he had only seen Beria on three or four occasions and that he had never solicited Beria's support on any matter. ${ }^{27}$ Arutinov ended his letter:

I ask of you that, in considering my dismissal, [...] the Presidium of the Central Committee [i.e. the Politburo] takes on board my explanation regarding $[\ldots]$ the expression of political distrust in me. ${ }^{28}$

Although he could not have known it at the time, Arutinov was perhaps more worried than he should have been. The expression of political distrust had earlier carried a peculiar charge at the highest levels of the political system because it signalled that an individual had fallen out of favour with the dictator. But with the dictator gone, the phrase no longer had the same meaning. In the event, the Central Committee resolution on his dismissal made no mention of 'distrust' at all but resorted to a much milder formulation on Arutinov's 'inability to manage his affairs.' ${ }^{29}$

Most often when they spoke or wrote of 'trust' (doverie), senior political leaders had the opposite in mind. They understood that in the event of the 'withdrawal of trust' or an expression of 'political distrust' in them, they were doomed. By contrast, evidence of what one might call positive trust at these levels is extremely hard to come by. One obvious reason for this is that there was probably very little of it. To talk, for example, of Stalin 'trusting' his deputies, or his deputies 'trusting' him, would be ludicrous. The relationships between the tyrant and his deputies were among the least trusting of any ruling circle of a leading state in the twentieth century. Stalin could dispose of his deputies as he wished and his relationships with them are perhaps the best-known example we have of 'power asymmetries

${ }^{26}$ RGASPI, f. 82, op. 2, d. 148 , 1. 36.

27 'Knowing his unfavourable attitude to Armenia we never sought his support. All matters concerning Armenia were presented to the Central Committee and the Council of Ministers via comrades Malenkov and Stalin'. Ibid., 11. 35-36.

${ }^{28}$ Ibid., 1. 38 .

${ }^{29}$ Resolution of 7 December 1953, Regional'naia politika N.S. Khrushcheva. TsK KPSS $i$ mestnye partiinye komitety 1953-1964 gg., Moscow, 2009, p. 595. 
[that] are so extreme that trust is driven out ${ }^{\prime}{ }^{30}$ The totalitarian theorists are almost certainly right in thinking that lower down the system trust was also in short supply. It is very likely, for example, that ambient levels of trust in Stalinist society were extremely low. Most Soviet citizens were unlikely to trust strangers, and even relationships with people they were close to (friends, relatives, lovers) were often blighted by distrust.

But this is not to say that there was no trust at all, even at the higher echelons of the political system. In order to understand this, we need to take account of two aspects of trust. The first is that most theorists of trust depict trust as a three-part relation. What they mean by this is that A will trust B to do a particular thing. To have 'blind trust' or trust over everything is rare. ${ }^{31}$ Most often we trust another person in relation to a particular area of competence or a particular action. Although in general, Stalin's deputies were not prone to trust each other, they may have trusted each other on particular matters. Secondly, like most dictators, Stalin was loath to have rules or institutions that might constrain him. He did, however, tolerate, and perhaps even encourage, primitive institutional devices that might sustain cooperation and, in turn, a more effective system of government. These devices could, over time, foster low-level forms of trust.

In order to draw out this latter point, let us consider Stalin's relations with his own Politburo deputies. Until the end of his life, all members of Stalin's ruling group understood that the dictator's decisions were unchallengeable and that his orders had to be implemented without demur. Given that it was ultimately Stalin's word that counted, it may be asked why he went to such lengths to ensure that other members of the ruling group put their signatures to Politburo decisions? ${ }^{32}$ One can view Stalin's system of co-signatures as a primitive institutional device to mitigate the high levels of distrust within the leadership. There were, indeed, other indicators of what we might call primitive institutionalization at the apex of the Soviet system under Stalin. The Presidium of the Council of Ministers, which was attended by all the Politburo members except for Stalin, and which convened on a weekly basis over several years, with detailed agendas, minutes, a clear division of labour, specialized support staff and an elaborate voting system, is one example. ${ }^{33}$ The experience

30 This phrase is from Farrell, 'Institutions and Midlevel Explanations', p. 131.

31 To cite Hardin: 'Only a small child, a lover, Abraham speaking to his god, or a rabid follower of a charismatic leader might be able to say "I trust you" without implicit modifier.' Hardin, Trust and Trustworthiness, p. 9.

${ }^{32}$ For evidence, see Yoram Gorlizki, 'Stalin's Cabinet: The Politburo and Decision Making in the Post-War Years', Europe-Asia Studies, 53, 2001, 2, pp. 291-312 (pp. 296-98).

33 On this, see Yoram Gorlizki, 'Ordinary Stalinism: The Council of Ministers and 
of systematically working together over several years, often helping each other out to solve joint problems, may have spawned forms of trust among Stalin's deputies on certain issues.

Unfortunately, the evidence on this, at least from the archives, is rather thin. Politicians, not least ones from the late Stalin period, tend to keep their motives close to their chest. In order to get at this we may have to approach the question obliquely. One way of doing this is to look at particular incidents and to reconstruct the personal dynamics that led up to them. Take, for example, the conspiracy that was forged against Beria after Stalin's death. If we are to believe his memoirs, Khrushchev understood that it was vital to win Malenkov over to his side, a fact confirmed by the responses of the other Presidium members when Khrushchev approached them with the idea of a plot. ${ }^{34}$ Yet Malenkov and Beria had worked closely in the late Stalin years and their bond was confirmed after Stalin's death. At the first meeting of the Presidium, Beria nominated Malenkov as Chair of the Council of Ministers while Malenkov reciprocated, nominating Beria as his deputy. At subsequent meetings Malenkov, as the chair, routinely supported Beria's policy proposals. The two were also seen walking together on the Kremlin grounds. ${ }^{35}$ Approaching Malenkov with the idea of dislodging Beria was therefore something of a risk for Khrushchev. Had Malenkov turned against him and sided with Beria, Khrushchev's position would have been in real jeopardy. But as close as Malenkov was to Beria, Khrushchev had attended regular meetings with Malenkov over a number of years and had formed a relationship of his own with him. When the cabal against Beria first met it was Khrushchev who volunteered to approach Malenkov. On the basis of his own assessment of Malenkov and his anticipation of Malenkov's reactions, one can say that, in this matter, Khrushchev placed his trust in Malenkov.

For signs of trust growing out of the interstices of existing institutions one may have to go beyond the realm of politics. Here the Harvard Interview Project, which included senior economic managers but virtually no party secretaries, provides some insights. Joseph Berliner's work on blat

the Soviet Neo-Patrimonial State, 1946-1953', The Journal of Modern History, 74, 2002, 4, pp.699-736 (pp. 703-18, 728-30).

34 'Kak derzhitsia Malenkov?' [sprosil Molotov]. [...] [Potom] Saburov ochen' bistro otvetil mne: 'Ia polnost'iu soglasen.' I tozhe sprosil: 'A chto Malenkov?' Ob etom sprashivali vse.' N. S. Khrushchev, Vospominannia. Vremia, liudi, vlast', 4 vols, Moscow, 1999, 2, p. 168.

35 'Ty [Malenkov] zhe sam ne daesh vozmozhnosti nikomu slova skazat'. Kak tol'ko Beria vneset predlozhenie, ty seichas zhe speshish podderzhat' ego, zaiavliaia: verno, pravil'noe predlozhenie, ia za, kto protiv.' Ibid., p. 166. 
suggested that certain forms of trust could grow out of ongoing business interactions among economic officials. In economic transactions, blat, he wrote is the knowledge of which persons are approachable for arranging deals, and the mutual trust which permits the deal to be initiated' ${ }^{36}$ Sometimes this 'mutual trust' was grounded in a pre-existing friendship or a family relationship. Often, however, it came out of an 'acquaintanceship' that had formed through business dealings over an extended period. 'Acquaintanceship played an important role', reported one of Berliner's informants. 'I always used to get my [supplies] from a particular store in Leningrad', affirmed another. 'Since I had always got it there, I had developed an acquaintanceship (znakomstvo) there.' 'In blat', as Berliner famously concluded, 'there is some personal basis for expecting a proposal to be listened to sympathetically, either because of past friendship, or because of the trust developed after a long business association' ${ }^{37}$

One of the important insights of Berliner's work is that an economic system that had previously been thought of as centralized, hierarchic and highly coercive, was in fact permeated at key pressure points by high levels of trust, and it was this trust that enabled the system to function more smoothly than it would otherwise have done. I want to suggest that a similar process may have been at work in the political sphere. Political relationships that were on the surface highly asymmetric and coercive may have contained within them kernels of trust.

\section{Structures of Trust after Stalin}

Berliner noted that although blat was reportedly 'the most significant word in contemporary Russia, it did not appear in Soviet publications..$^{38}$ The kinds of political trust I focus on here did not appear in the press, were hardly reflected in the archives and, unlike business practices, were not even discussed in the Harvard Project. In a sense, the fact that political trust was not overtly spoken about is not surprising; by its nature, where true trust exists, it tends to go unsaid. Still, the types of trust that Berliner wrote about were most often among hierarchic equivalents, for example between supply agents (tolkachi) and ministerial administrators. Even more so than with the economic system, the Soviet political order was extremely hierarchic and coercive, conditions not normally associated with trust. How did trust take root in such circumstances?

\footnotetext{
${ }^{36}$ Joseph S. Berliner, Factory and Manager in the USSR, Cambridge, MA, 1957, p. 182.

37 Ibid., pp. 187-88, 191 (italics mine).

38 Ibid., pp. $183-84$.
} 
Recent research has highlighted ways in which trust may emerge out of coercive and asymmetric power relationships. Studies of social work bureaucracies, for example, have shown how micromanagement of performance may lead subordinates to withdraw effort and loyalty; superiors may then compensate for this by supplementing the formal institution with informal relations of trust, sometimes even taking responsibility for the actions of those they supervise and affording them political 'cover'. ${ }^{39}$ Trust may also be compatible with outright coercion. In order to understand this, let us recall that the problem of trust exists where the truster experiences genuine uncertainty over whether the trusted will cooperate in a certain matter. However, as Diego Gambetta suggests, 'all too often the problem of trust is looked at from the point of view of the truster. In so many instances, however, matters are in the hands of trustees, who want to be trusted just as much as others may wish to trust them'. ${ }^{40}$ Key to resolving the problem of trust is that the trusted is keen to find some device that will reassure the truster that they will behave in a trustworthy manner. ${ }^{41}$

One mechanism through which the trusted can signal trustworthiness is what Gambetta calls 'self-inflicted blackmail'. Given that this is somewhat counterintuitive, it is worth citing Gambetta at length:

Consider the following situation, in which an agent is desperate to be trusted by another: 'both the kidnapper who would like to release his prisoner, and the prisoner, may search desperately for a way to commit the latter against informing on his captor once released, without finding one' [...]. The kidnapper fears that once freed the victim will inform on him, thus the deal falls through [...]. Not all is lost however. Thomas Schelling, who conceived the above example, also suggested the solution: 'If the victim has committed an act whose disclosure could lead to blackmail, he may confess it [to the kidnapper]; if not he might commit one in the presence of his captor, to create the bond that will ensure his silence. ${ }^{32}$

39 See Cook, Hardin and Levi, Cooperation without Trust?, pp. 133, 141-45; John Brehm and Scott Gates, 'Supervisors as Trust Brokers in Social Work Bureaucracies', in Roderick M. Kramer and Karen S. Cook (eds), Trust and Distrust in Organizations: Dilemmas and Approaches, New York, 2004, pp. 41-64.

${ }^{40}$ Gambetta, Codes of the Underworld, p. 37.

${ }^{41}$ The example Gambetta gives is of a would-be criminal who gives out his telephone number and reveals his whereabouts and of those closest to him in order to reassure a gang that he is trustworthy. Ibid., pp. 40-41.

${ }^{42}$ Ibid., p. 59, citing Thomas Schelling, The Strategy of Conflict, Cambridge, MA, 1960, pp. 43-44. 
In other words, argues Gambetta, we may have an interest in 'volunteering negative information about ourselves'. 'Being bad', he writes, 'and displaying credible evidence of it can make our promises credible'. 'There are instances', he continues, 'when there is an advantage to opening up one's cupboard for others to see the skeleton'. In some environments - parts of the Stalinist system come to mind - the potential stock of ambient trust was so low that 'blackmail may have been the only route to cooperation'. Indeed, suggests Gambetta, in such low-trust environments 'kompromat [may be] willingly offered, [making] oneself blackmailable in order to be trusted'. ${ }^{43}$

Gambetta writes about the exchange of information and the willing provision of information by the trusted to the truster. In the Soviet Union under Stalin we encounter a slightly different situation. Here there was a large stock of compromising information available to superiors, normally through the agencies of the security police. The extension of Gambetta's argument is that although it was not explicitly 'exchanged' the sheer existence of this information could, paradoxically, have had a stabilizing role by enabling superiors to trust their subordinates more.

In order to explore this issue, let us look more closely at relationships among politicians at the regional level. What we are especially interested in are what the sociologist James Coleman referred to as the 'structures of ongoing relationships. ${ }^{44}$ The security police often played a key role in structuring these relationships, but unfortunately their archives remain closed. Given the dearth of reliable information I shall confine myself to two rather stylized examples, one from the late Stalin period and one from immediately after Stalin's death. While we cannot vouch for the representativeness of these examples, they do point to what appears to have been an underlying shift in the 'structures of ongoing relations' among politicians at the regional level.

We begin by looking at the network around Mir Dzhafar Bagirov in Azerbaijan on the eve of Stalin's death. It is relevant to Bagirov's story that prior to becoming First Secretary of the Republic in 1933 he had served for eight years (1921-27, 1929-30) as head of the republic's secret police. In that capacity he had not only come to know Beria (as his direct line manager

43 Gambetta, Codes of the Underworld, p. 59, and Diego Gambetta, personal communication, 1 December 2008.

${ }^{44}$ James S. Coleman, The Foundations of Social Theory, Cambridge, MA, 1990, cited in Hardin, Trust and Trustworthiness, p. 83. Note that elsewhere Coleman (ibid., p. 175) writes of 'systems of trust' (cited in Piotr Sztompka, Trust: A Sociological Theory, Cambridge, 1999, pp. 61, 110). 
from 1921-22), but had become closely acquainted with the murky world of informers and double-agents, both within the Soviet Union and abroad, and with the various forms of manipulation and blackmail that were routinely applied by the Soviet security services. One of the direct legacies of Bagirov's spell in the Cheka/GPU was an extremely coercive approach to his perceived opponents, one that would last throughout his career. ${ }^{45}$

According to one largely credible source, a letter from the former security agent, L. K. Efendiev, to Khrushchev of early October 1953, Bagirov had:

converted the Ministry of Internal Affairs into a kind of supra-party agency, an obedient tool for implementing his dirty deeds. (Their method was always the same.) This agency developed the idea of the politically unreliable person, the 'PN' [politicheskii neblagonadezhnyi], into an instrument that Bagirov could use as and when he wished. Bagirov turned the ministry into a workshop for fabricating forged documents and creating false charges against all those who were not with him [kto emu ne po dushe]. ${ }^{46}$

One of the ministry's favoured methods was the use of kompromat against Bagirov's opponents. Efendiev gave the following example. Set on neutralizing the former Secretary of the Azeri Central Committee, Aziz Aliev, Bagirov had him recalled from Moscow to Azerbaijan, and then

45 According to one well-documented report compiled by the Central Committee in December 1953, in twenty districts alone over the previous two years Bagirov had had sacked, and in most cases had successfully prosecuted, 134 raikom secretaries and raiispolkom chairs, while across the republic 874 heads of cattle farms had been arrested, almost entirely, as far as the report could tell, on trumped-up charges. Over the same time frame, in 1951 and 1952, criminal cases had also been fabricated against Bagirov's adversaries including, among others, a variety of whistle-blowers, journalists, heads of party electoral commissions and members of various putative 'anti-party' groups. RGASPI, f. 82, op. 2, d. 148, 11. 14-17.

${ }^{46}$ RGASPI, f. 82, op. 2, d. 148, 1. 9. Efendiev certainly had an animus against Bagirov, having been imprisoned by him the previous year. Nonetheless, most of the evidence presented by Efendiev in his thirteen-page letter of 5 October 1953, appears to have been well-founded. Efendiev had worked for over thirty years in the Azeri secret service and many of his allegations, for example about the Starostyn Affair, were later corroborated. Sent originally to Khrushchev, the letter was circulated to all members of the Presidium and may well have triggered Bagirov's dismissal later that month as Chair of the Azeri Council of Ministers (Bagirov was arrested the following March and executed in 1956). The Central Committee report of 15 December in the same file as the Efendiev letter confirmed, on the basis of a separate investigation, that 'all these claims do in fact reflect the true situation in the republic under Bagirov'. Ibid., 1. 14. The Efendiev letter is in ibid., 1l. 1-13. 
gave the MVD the task of preparing a case that he was a 'PN' - that is 'for having concealed his visit (if needs be, in his childhood) to Iran, to have him removed'. So this person, a doctor of science, is reduced to dragging out a miserable existence, and is in effect destroyed [iznichtozhen]. By these very methods Ali Ashraf Ali zade, S. Vezirov, Makmud Aliev (whom Molotov knows) have been 'taken out'. That was the method and style of Bagirov's 'work'. ${ }^{47}$

\section{A Central Committee report in December concurred:}

All those who have their own views [...] are cruelly persecuted and blackmailed and openly threatened with being 'left to rot' in prison or 'being chased out of Azerbaijan' [...]. Many leading functionaries have been persecuted by means of compromising materials [komprometiruiushye materialy] and are either evicted from the republic or, when they themselves can't take it any longer, they just leave of their own accord. ${ }^{48}$

Key to understanding the dynamics of Bagirov's network was that he used kompromat not only on his enemies but, as systematically, on his friends and allies as well. According to Efendiev, Bagirov's 'best friend', whom he promoted as Secretary of the Presidium of the Supreme Soviet, was in fact the former 'officer of the Turkish Army, Musa Shamsadinskii'. Shamsadinskii was by no means a one-off:

The party has opened its arms to Mekhti bek Safaralibekov (brother of Mussatavist Shirinbek Safaralibekov, executed in 1937) and to Bagatur Eivazov (son of the bourgeois nationalist Asker bek Eivazov). Bagirov was shown a document from the (Panturkic) journal 'Feviazit' where Mir Kasimov Mir Asadully had issued a call from Turkey to the Mussavat intelligentsia in Azerbaijan to rise up. What does Bagirov do? He promotes him to the position of President of the Azeri Academy of Sciences, knowing full well that as a scholar (a surgeon) he is not up to much, and he makes him a deputy of the USSR Supreme Soviet as well. All these counterrevolutionary elements who have served time in prison - Ismail zade, Ataevy, Musabekov (whose whole family were executed), Shakhsuarov,

47 Ibid., 1. 10.

${ }^{48}$ Ibid., 1l. 17-18. Examples given were of the Second Secretary of the republic, Samedov, the secretary of the Baku gorkom, Gezalov, the former head of department at the gorkom, Abmova-Skirskaia, 'and others'. For another reference to the use of 'komprometiruiushye materialy', this time against the head of department at the Kirovobad gorkom. See ibid., 1. 16. 
Rzabeili etc. now head departments at the Azerbaijan medical institute, but as much as the party organization tries to kick up a fuss, it has been impossible to convince Bagirov, a firm friend of these people [ubezdhennyi drug etikh liudei], of the unacceptability of the situation. ${ }^{49}$

Efendiev went on to reel off a long list of names of individuals with questionable pasts who had gone on to senior positions in the Azeri leadership before commenting sarcastically about 'the strange dulling of [Bagirov's] political vigilance over a relatively long period, the peculiar "sentimentalism" he has shown towards enemies of our party, the striking "patronage" he has exercised over any anti-Soviet gang. ${ }^{50}$

Efendiev certainly had an axe to grind against Bagirov. However, many of these allegations and others like them were confirmed in the Central Committee investigation on Bagirov, whose findings were reported in December $1953 .{ }^{51}$ 'Many of those lodging complaints have demonstrated', it noted, 'that Bagirov has elevated to leading positions those who do not inspire political trust, those who have failed in their previous work. ${ }^{52}$ What the report pointed to were not isolated cases, but a clear pattern of behaviour. To highlight this aspect, this part of the report is worth quoting in full:

Over a number of years Bagirov has grossly violated party principles for the selection of cadres and promoted to leading positions those who do not inspire political trust, rather keeping on those who are personally devoted to him and with whom he has close relations. Along with outand-out political criminals and rascals such as the now arrested SumbatovTopuridze he has elevated to top-ranking positions people of bourgeoiskulak origin, sons of policemen, those with close kin in emigration and those compromised by their past work. So, until very recently the Minister of Industrial Building Materials was the son of the famous millionairebanker Dadashev (with the son also being married to Bagirov's niece). The son of the prominent merchant Aliev was made Secretary of the Azeri Central Committee, after which he was made President of the Republic's

49 Ibid., 1l. 7-9 (italics mine).

${ }^{50}$ Ibid., ll. 11-12.

${ }^{51}$ Efendiev sent the letter knowing full well that its assertions would be checked up by the Central Committee apparatus. He also traces the fates of individuals that he claims members of the Presidium, such as Molotov and Malenkov, 'personally knew'. The one area where he does slip up is when he claims that Bagirov had temporarily lost his position in Azerbaijan in 1932; in fact this appears to have happened in 1930. Cf. ibid., 11. 5-6.

${ }^{52}$ Ibid., l. 14. 
Academy of Sciences. A long-serving Secretary of the Azeri Central Committee was comrade Seidov, many of whose relations were repressed for anti-Soviet activity or are now based abroad (at present Seidov is head of the republican Gosplan). Having removed comrade Gasanov from the post of Republican Party Secretary for his connections to his politically dubious relatives, Bagirov nonetheless retained him as head of the Department of Science and Culture. Bagirov promoted to the head of the IndustrialTransport Department comrade Gasan-Zade, who had concealed from the party his social origins and the convictions of his close relatives for antiSoviet activity. Comrade Aidinbekov, who had been removed by a decision of the All Union Central Committee from the post of Chair of the Council of Ministers in Dagestan and received a party reprimand for slander, was appointed by Bagirov as Minister of Trade in Azerbaijan; and so on and so on. All these people were necessary to Bagirov so that, in relying on them, he was always sure to have his way. ${ }^{53}$

The idea that Soviet leaders could systematically use kompromat to tie subordinates to them is not new. ${ }^{54}$ Recently, Paul Gregory has shown how in the security police Stalin systematically promoted those with 'compromised backgrounds' on whom 'he had the goods' and that this pattern was replicated at lower levels of the NKVD. 'Stalin's Praetorians', he writes, 'were [...] a sorry lot [...] highly compromised by current and past transgressions $[\ldots]$ their flaws made them dependent on their patron'.55 But what does this have to do with trust? Systematic blackmail and the accumulation of discrediting information on individuals would appear, on the surface, to be the very opposite of trust. In order to understand the relationship between the two one should bear in mind that in a republic such as Azerbaijan in the late Stalin period kompromat was woven into the very fabric of government and had become an integral component of Bagirov's method of rule. ${ }^{56}$ The situation in Azerbaijan in this period may

53 Ibid., 1l. 18-19.

54 Many years ago, Barrington Moore wrote that 'many successful administrators have some blot on their record that can be brought out against them at any time Moscow chooses. In one respect this is excellent from Moscow's viewpoint, since it means that the central authority has a hold over its lieutenants'. Barrington Moore, Jr., Terror and Progress USSR, Cambridge, MA, 1954, p. 21. For a more general discussion of the principle of 'suspended punishment', see Alena V. Ledeneva, Russia's Economy of Favours: Blat, Networking and Informal Exchange, Cambridge, 1998, pp. 77-79, and Alena V. Ledeneva, How Russia Really Works: The Informal Practices that Shaped post-Soviet Politics and Business, Ithaca, NY, 2006, pp. 13, 85.

55 Paul R. Gregory, Terror by Quota: State Security from Lenin to Stalin (An Archival Study), New Haven, CT and London, 2009, pp. 45, 58, 61-62.

${ }^{56}$ Albeit to a lesser extent, this has parallels with the use of kompromat in the post- 
indeed have been subtly different from the one portrayed by Gregory in his study of the security police. Gregory depicts a highly unstable equilibrium, well captured by Stalin's observation that the 'Checkists have only two paths - advancement or prison'. ${ }^{57}$ In Azerbaijan, however, the situation may have been somewhat different. From the late 1930s onwards a group of security officials managed to carve out long-term niches for themselves based on the practices of kompromat and blackmail. ${ }^{58}$ Once established, these officials provided a platform for a particular kind of trust that would become indispensable for their survival.

Let us consider the head of the Azerbaijani security police from 1939 to Bagirov's departure in 1953, S. F. Emel'ianov. Emel'ianov was entrusted by Bagirov with some of the most delicate operations, including those designed to ward off high-level brigades and investigators from Moscow. Probably the best-known example of this was in May 1948 when a large group of inspectors of the USSR Ministry of State Control, based in Moscow, along with two deputy ministers, were sent to the republic to investigate financial irregularities there. The brigade soon uncovered numerous examples of malfeasance, including corruption, bribery and protectionism. Instructed by Bagirov to 'break the case', Emel'ianov arranged for the two deputy ministers, Starostyn and, by chance, another Emel'ianov, and their teams, to be plied with drinks and visited by a posse of young women with whom they were secretly filmed in an orgy. The Ministry of State Control was forced to beat a hasty retreat and the case was dropped. ${ }^{59}$ In another case in 1951, verified in the Central Committee

Soviet period. Writing of El'tsin's bodyguard, Aleksander Korzhakov, Chrystia Freeland observed: 'People feared him and that fear, which is part of the Russian political tradition, in many ways anchored the vertical power of the Russian state. Korzhakov collected dirt; he knew who every governor was sleeping with, who was paying him bribes and so forth.' Chrystia Freeland, Sale of the Century, London, 2000, p. 226, cited in Ledeneva, How Russia Really Works, p. 78 (italics mine). Chapter three of Ledeneva's book has a useful discussion of the uses of kompromat in the post-Soviet period.

57 Cited in Gregory, Terror by Quota, p. 54. During a major purge, such as in 1937-38, things were even worse for officials of the security police, who faced the 'repressors' dilemma' of either being 'punished early' or being 'punished late in the game'. Ibid., p. 221.

${ }^{58}$ Note the contrast with the first phase of Bagirov's rule. Many of those who had come close to him in 1920s, were repressed in 1937/38. Examples include Ali Bek Zizikskii, Akhmed Bedin (Trinich), Mamed Emin Rasul and Abaskuli Kiazim zade. RGASPI, f. 82, op. 2, d. 148, 11. 2-5.

59 Iu. V. Rubtsov, 'Reviziia Mingoskontrolia SSSR 1948 goda v Azerbaidzhane: revansh praviashei elity', Otechestvennaia Istoriia, 2002, 2, pp. 158-61; E. Ismailov, Vlast' $i$ narod. Poslevoennyi stalinizm v Azerbaidzhane 1945-1953, Baku, 2003, pp. 225-26; Tsk VKP(b) $i$ Regional'nye partiinye komitety 1945-1953, Moscow, 2004, pp. 113-20; RGASPI, f. 82 op. 2 , d. 148 , ll. 9-10. 
report, Emel'ianov, under orders from Bagirov, fabricated a case against an 'Armenian national grouping' which included the deputy minister of timber industry, the minister of food industry, and the deputy minister of trade. ${ }^{60}$ In general, concluded the Central Committee report of December 1953 ,

Bagirov did not tolerate the intervention of central agencies in Azerbaijan's affairs, he tried to discredit anyone sent by Moscow to the republic to investigate its organizations [...]. [Over the years] Bagirov tried to bring into disrepute functionaries from the USSR Ministry of Transport, the USSR Ministry of Industrial Building Materials, [the USSR Ministry of Justice], journalists from Pravda and Gudok and functionaries from the Central Committee apparatus. In order to blacken these functionaries, Bagirov would sink to the lowest methods, up to and including outright provocation. $^{61}$

Fighting off official inquests from the centre was a risky business. Discrediting high ranking officials from Moscow, who no doubt had contacts and forms of leverage of their own, was an undertaking that could easily have backfired. In order to do this, Bagirov had to turn to someone he could trust. Although no evidence has been found, one could plausibly hypothesize that Bagirov had kompromat on Emel'ianov, and that this kompromat may have initially formed the basis of their relationship. Yet such kompromat was probably in and of itself insufficient for Bagirov to rely on Emel'ianov in such testing circumstances. The fact that Emel'ianov had worked for Bagirov for over a decade almost certainly played a role. Over that time Bagirov had come to know Emel'ianov and had formed an opinion of his personal qualities and of his likely behaviour when confronted with a major dilemma. One can say that in this particular area of his activities Bagirov had come to 'trust' Emel'ianov. Nor was kompromat-based trust confined to the relationship between Bagirov and Emel'ianov. Emel'ianov, in his turn, had to rely on other officials to do his dirty work for him. In order to ward off the attentions of the centre, Bagirov and Emel' ianov held together a sizeable network of officials whose ties to each other, one can suppose, were similar to those that bound Emel'ianov to Bagirov.

${ }^{60}$ Ibid., 1. 17.

61 Ibid., 1. 20. 
Our research on regional networks in the late Stalin period suggests that the situation in Azerbaijan was probably somewhat anomalous. ${ }^{62}$ Yet while it was an extreme case, one can hypothesize that the systematic use of confidential information on former 'counter-revolutionary activity', on those with class-alien social origins, or on the existence of relatives abroad, remained rife until the end of Stalin's life. In this system, the role of the security police in digging up information, storing it, and releasing it at opportune moments, was crucial. With Stalin's death, the institutional arrangements for kompromat changed. First, Stalin-era rules on class backgrounds and on former 'counter-revolutionary' activities were relegated in importance and often entirely overlooked. By the mid 1950 s personnel forms were reorganized in recognition of this. On 15 June 1955 a Central Committee report noted that the party's cadre forms inherited from the Stalin era had 'replaced proper political vigilance with harmful suspiciousness and cultivated the condemned practice of a biological approach to cadres'. The report noted that the country was now dominated by a generation who had been politically socialized after the consolidation of Soviet power and it asked, therefore, why cadre forms continued to have questions on service in the imperial army and in the tsarist police, on support for the White Army, participation in the 1920s opposition, and so forth. 'It is also well known', the report added, that:

during the period of the Great Patriotic War a large part of the population of the USSR was forced to live in areas captured by fascist forces. In these conditions one's presence [...] on occupied fascist territory cannot be regarded as something that reflects badly on an official. Meanwhile, this question remains on the form and can be used as a compromising fact about a person.

Similarly, the report noted that the question of whether a respondent or their relatives had ever been convicted of a crime was now not always relevant:

In their time very many Soviet people, and among them tens of thousands of communists and members of the Komsomol, faced criminal prosecution for quite trifling misdemeanours.

${ }^{62}$ This is based on the findings of our ESRC project on 'Networks and Hierarchies in the Soviet Provinces, 1945-1970'. See <http:www.socialsciences.manchester.ac.uk/ sovietprovinces $>$ [accessed 15 October 2012]. 
Ten days later, the Presidium of the Central Committee resolved to eliminate such 'office-bureaucratic distortions in record-keeping on cadres'. ${ }^{63}$

The fact that information that had once been systematically used for Stalin-era kompromat was now downgraded did not mean that there were no longer grounds for kompromat. Once de-Stalinization proper got under way, it was now, conversely, the fact that a leader had been a perpetrator of Stalin-era repressions that became the main source of political kompromat. This was the second main change that was to occur with Stalin's death. Related to this was the fact that the main agency for storing and processing this information was no longer the security police. All leading politicians from the Stalin era were one way or another heavily involved in mass repressions. The key thing was to control information on this. For much of the 1950 s the main repositories of information on 'unlawful prosecutions' were the high level rehabilitation commissions, many of which were led by Khrushchev's clients, most notably the Procurator-General Roman Rudenko.

In order to highlight the role of the new post-Stalin kompromat and of how this could foster ties of trust let us consider the case of Frol Kozlov. At the beginning of 1949, as the Leningrad Affair took off, Kozlov was transferred from Kuybishev, where he had served as obkom Second Secretary, to head the party organization at the huge Kirov plant in Leningrad. Later that year he was appointed Second Secretary of the Leningrad gorkom, where he served directly under Vasilii Andrianov and where he was credited by some, along with Andrianov, with seeing through the Leningrad purge. It was a measure of Kozlov's success in this role that in 1950 he was promoted as First Secretary of the gorkom and two years later he became the Second Secretary of the regional party committee. Yet this close association with the Leningrad Affair was soon to turn into a major headache for Kozlov. One of the first repercussions of Beria's arrest and of the Central Committee plenum in July 1953 was the reopening of the files connected with the Leningrad case.

At the beginning of 1954 Kozlov's position had become precarious. A sizeable portion of the regional party organization had taken against him for his role in the Leningrad repressions, where many had lost friends and relatives only a few years earlier. This much was reflected at the February 1954 obkom conference, where no fewer than 125 people (19 per cent of the delegates) voted against Kozlov's candidacy at the obkom elections. ${ }^{64}$

63 Arkhiv Presidentskii Rossiiskoi Federatsii (APRF), f. 3, op. 23, d. 153, 1l. 34-36, 44-48.

${ }^{64}$ RGASPI, f. 556, op. 14, d. 25, 1. 65. 
On 25 April Pravda published an attack on Kozlov for his insufficient 'self-criticism' and for failing to address shortcomings in the regional party organization. ${ }^{65}$ All along, Kozlov was well aware that the report of the Central Committee commission into the Leningrad Affair was due to come out at any moment. Khrushchev had earlier shown confidence in Kozlov by overseeing the latter's promotion as First Secretary of the obkom during a visit to Leningrad in December 1953, but it was now that Khrushchev's support for Kozlov was to be at its most valuable. On 3 May the Procuracy's report on the Leningrad Affair, authored by Rudenko, was presented to the Presidium of the Central Committee, and certain of its recommendations were approved. Three days later, Rudenko addressed a full meeting of the Leningrad party aktiv elucidating at length on the recent Central Committee resolution on the Leningrad Affair. ${ }^{66}$ The following day Khrushchev himself addressed the aktiv, making it quite clear that Kozlov should not be held at fault for what had happened in the city: 'There are certain people here who blame comrade Kozlov and others. But if Kozlov is responsible for the "Leningrad Affair" then I am even more to blame.' Playing on words, he went on, 'One must not look for a scapegoat here, even though your First Secretary is a goat by name. [Nel'zia iskat' kozla opuscheniia, khotia familiia u vashego sekretaria i Kozlov.] (Laughter in the hall.) ${ }^{67}$

The nature of Kozlov's dependence on Khrushchev was widely understood by those around Khrushchev and became a structural feature of Kozlov's position that limited his room for manoeuvre. One of the most acute observers of this structural dependence was another of Khrushchev's acolytes, Dmitrii Shepilov, who accompanied Khrushchev on an earlier visit to Leningrad, in December 1953:

After Stalin's death, I, as editor in chief of Pravda, accompanied Khrushchev to a meeting of party activists in Leningrad [...] the meeting's presidium, of which I was a member, received many notes demanding that Andrianov and Kozlov be brought to justice for violating socialist legality, smashing the Leningrad organization, and deliberately defaming its members. During the breaks, many party activists asked me, 'Why is Frol Kozlov still Secretary? Why aren't Kozlov and Andrianov made to answer for what they did?' [...] I told Khrushchev about the notes and what had been

${ }^{65}$ Cited in Wolfgang Leonhard, The Kremlin Since Stalin, Oxford, 1962, p. 29.

${ }^{66}$ A. Artizov et al. (eds), Reabilitatsiia - Kak eto bylo: dokumenty Prezidiuma TSK KPSS i drugie materialy, 3 vols, Moscow, 2000-04, 1, pp. 115-16, 117-29.

${ }^{67}$ Ibid., pp. 130, 134. 
said to me at the meeting. 'It's my impression,' I said, 'that the communists here are unanimous about the need to dismiss Kozlov immediately as Leningrad Secretary. I think Kozlov himself recognizes that he has no respect or support from among the activists.' Khrushchev was silent. I continued along the same line, citing more facts and arguments. 'All right, all right,' Khrushchev said, 'we'll see.' [...] Speaking at the meeting the next day, Khrushchev made an astounding statement: 'As for Comrade Kozlov, if you support him, the Central Committee will too.' I soon realized that Khrushchev made frequent use of such tactics. He chose some failed and discredited official, appointed him to a high post, rewarded him with various titles, and made him into his most loyal and obedient servant. This protégé understood that his welfare, titles, posts and entire comfortable life depended totally on his benefactor. One word from the latter, and all was lost. ${ }^{68}$

The main feature of Kozlov's dependence on Khrushchev was that it was based on a new structural device that had only appeared since Stalin's death, the strategic assignment of blame for Stalin-era repressions. Other politicians, such as Malenkov, were later implicated, on Khrushchev's instigation, in the Leningrad Affair, and Khrushchev could have, at any stage, decided to turn the heat on Kozlov. Khrushchev's attack on Malenkov at the January 1955 Central Committee plenum indeed spawned a new wave of attacks on Kozlov in Leningrad. 'Andrianov was the main intriguer', it was said at the meeting of the Electrosila factory on 23 February 1955, 'but Kozlov does not want to acknowledge his own mistakes. ${ }^{69}$ According to the Central Committee official, Storozhev, discussion of the January 1955 Central Committee plenum in Leningrad demonstrated 'that there is still a lot of dissatisfaction with the fact that the leadership of the obkom and the gorkom still has those who were involved in the Leningrad Affair'. He went on:

After the January plenum, it has been hard for comrade Kozlov to work as a Secretary of the Leningrad obkom. In the organization they remember what role he played in the destruction of the [Leningrad] 'anti-party group' and in getting rid of cadres. Feeling his own moral accountability, Kozlov has not been able to meet the high level of expectations of the workers when it comes to criticism and self-criticism. ${ }^{70}$

${ }^{68}$ Dmitrii Shepilov, The Kremlin's Scholar: A Memoir of Soviet Politics under Stalin and Khrushchev, New Haven, CT and London, 2007, pp. 153-54.

${ }^{69}$ RGASPI, f. 556, op. 14, d. 25, 1. 64.

${ }^{70}$ RGASPI, f. 556, op. 14, d. 25, 1l. 65-66. 
Such a state of affairs was ideally suited to Khrushchev. Knowing that he had strong leverage over Kozlov he promoted him, first bringing him into the new Russian buro of the Central Committee in March 1956, and then making him a candidate member of the Central Committee Presidium in February 1957. On the basis of the qualitatively new type of kompromat he had on him, and of his own personal relationship with Kozlov, whom he had got to know during several visits to Leningrad since Stalin's death, Khrushchev came to the view that he could count on him.

Soon after his admission to the Presidium [i.e. the Politburo] Kozlov was presented with a golden opportunity to show his worth to Khrushchev. On 18 June the Presidium of the Council of Ministers, headed by Bulganin, requested that an emergency meeting of the Presidium of the Central Committee be convened, ostensibly to discuss the text of the speech that was to be given at the forthcoming 250th anniversary celebrations of the founding of Leningrad. During the meeting of the Presidium, six full members called for Khrushchev's resignation as First Secretary. Khrushchev and his one ally at the meeting, Mikoian, insisted that since certain members of the Presidium were away, any decision would have to await a full meeting of the Presidium. One of the non-voting members who was absent from the meeting was Kozlov who, as First Secretary of the Leningrad obkom, had stayed in the city to make arrangements for the forthcoming celebrations. ${ }^{71}$ When the two factions on the Presidium reached an impasse, Khrushchev's allies decided to outflank the Presidium opposition by summoning all the Central Committee members to Moscow and asking for a convocation of the full Central Committee. In this matter Kozlov was to play a key role, since a large number of the Russian obkom secretaries, who were also members of the Central Committee, had already gathered in Leningrad for the 250th anniversary. Kozlov brought the assembled Central Committee members then in Leningrad with him directly to Moscow. ${ }^{72}$

'In the first instance', writes Khrushchev's son, Sergei, '[my father] had believed that it was imperative to get in touch with the First Secretary of the Leningrad obkom, Kozlov. My father had reckoned in particular on Kozlov's support. ${ }^{73}$ Along with Ignatov, the First Secretary of the Gorkii obkom,

${ }^{71}$ Also absent from the first meeting were the full members of the Presidium Kirichenko, Saburov and Suslov and the other non-voting member Mukhitdinov. Georgii Zhukov arrived an hour and a half late. V. V. Zhuravlev (ed.), XX s"ezd KPSS i ego istoricheskie real'nosti, Moscow, 1991, p. 49.

72 Roy Medvedev, 'N. S. Khrushchev. God 1957-iy - ukreplenie pozitsii', in Nikita Sergeevich Khrushchev: Materialy k biografii, Moscow, 1991, pp. 43-44.

73 Sergei Khrushchev, Nikita Khrushchev: krizisy i rakety, Moscow, 1994, p. 312. The 
Kozlov played a key role in drafting a letter, signed by eighty members and candidate members of the Central Committee to the Presidium, insisting on a convocation of the Central Committee, and in the delivery of this letter to the Presidium. In the end, as is well known, Khrushchev and the Central Committee majority prevailed over what would become known as the 'Anti-Party Group'. In an emergency situation, with his back to the wall, Khrushchev counted on Kozlov's support. Although it had its origins in Khrushchev's manipulation of Kozlov's 'compromised past' this foundation served as a basis for Khrushchev to place his 'trust' in Kozlov in this particular matter. Indeed, Khrushchev's son suggests that his father settled on Kozlov as his successor. 'He trusted him more and more [emu vse bol'she doverialsia otets], although their relationship was not without its conflicts and its sharp skirmishes. ${ }^{74}$

\section{Why Trust?}

The Soviet Union under Stalin and in his immediate aftermath was not a trust-free zone. I have suggested, moreover, that ties of trust were to be found where one might least have expected them, at the very core of the political system. Ties of trust were often predicated on practices that had become engrained in the Soviet political system. In some cases, as in the USSR Council of Ministers, these were institutionally-governed rule-bound practices which could support forms of trust on certain issues among Stalin's deputies. In other situations, such as in Azerbaijan in the late 1930 s and 1940s, which were characterized by exceptionally high levels of uncertainty, trust among officials could derive from more esoteric sources. Here, kompromat - information that was systematically generated and stored by the secret police in order to manipulate subordinates - emerged as a kind of a quasi-institution that could support certain forms of trust. As in the criminal underworld, the significance of such governancethrough-kompromat is that it suggests that some forms of trust may emerge in environments marked by high levels of coercion. Although kompromat continued to be practised after Stalin, for the rest of the $1950 \mathrm{O}$ its underlying principles were reversed, for they were now founded on the values that were opposed to the arbitrary violence and secret policedominated practices of the Stalin years.

two other figures who played a major role in getting in touch with Central Committee members and transporting them to Moscow were Marshal Zhukov and the head of the KGB, Ivan Serov. By 21 June 107 of the 130 voting members of the Central Committee were in Moscow and by the following day 122 had arrived. See ibid., pp. 311-13; Zhuravlev, XX s"ezd KPSS, pp. 51-52.

74 Sergei Khrushchev, Pensioner soiuznogo znacheniia, Moscow, 1991, pp. 25-26. 
We noted earlier that while Soviet leaders freely used the term trust in the negative (as 'political distrust' or the 'withdrawal of trust') they were much more reluctant to use the term in a positive sense. Our search through the archives has revealed very few instances of positive interpersonal trust (doverie) being spoken about by political actors in the 1940 s and ' 50 . In this sense there was a contrast with the Brezhnev era, when the term trust (doverie) was widely bandied about by politicians, and where a variant of the term (doverie $k$ kadram) was even turned into a key part of the regime's ruling ideology. ${ }^{75}$ We have also seen that in those instances where we have posited ties of trust over certain issues (Khrushchev and Malenkov over Beria, Bagirov and Emel'ianov in the Starostyn affair, and Khrushchev and Kozlov in the 'Anti-Party Affair'), the evidence that we have is, of necessity, indirect. In none of these cases do we have incontrovertible evidence that the parties to the hypothesized trust relationships thought of them as such. Given the difficulties of proving the existence of trust, why should we persist with this term? Why not opt, as other scholars have done, often with great success, for another term, such as 'loyalty' or 'objective loyalty'? ${ }^{76}$ It seems to me that there are two reasons why we should, to cite Gambetta, 'trust "trust". The first is that trust as a term of inquiry and concept is widely used across the humanities and social sciences. The comparative literature on trust has generated findings which can be fruitfully applied to the Russian and Soviet cases; equally, it may be hoped that research from the Russian case can feed into wider comparative work on trust. ${ }^{77}$ In order to convey the second benefit of using trust we should return to our understanding of what trust is. Most theorists argue that acting on trust involves risk. The truster stands to lose something that is important to her while the trusted has the real option of disappointing the truster, and thereby exercising a certain measure of freedom. Looking at trust in the Soviet Union allows us to benefit from the wealth of new

75 See Yoram Gorlizki, 'Too Much Trust: Regional Party Leaders and Local Political Networks under Brezhnev', Slavic Review, 69, 2010, 2, pp. 676-700.

${ }^{76}$ The term loyalty is used to great effect in the two outstanding works on cadre politics in this period: T. H. Rigby, 'Khrushchev and the Rules of the Game', in R. F. Miller and F. Feher, Khrushchev and the Communist World, London, 1984, pp. 39-81, and Charles H. Fairbanks, Jr., 'Clientelism and Higher Politics in Georgia, 1949-1953', in Ronald Suny (ed.), Transcaucasia: Nationalism and Social Change, Ann Arbor, MI, 1983, pp. 339-68. It has also been used more recently by Gregory, Terror by Quota, pp. 45, 80.

77 The Soviet archives provide exceptionally rich source materials on closed trust networks of a kind that parallel the Enron fiasco in the USA and the Royal Bank of Scotland scandal in the UK. For a detailed case study, see Yoram Gorlizki, 'Scandal in Riazan: Networks of Trust and the Social Dynamics of Deception', forthcoming in Kritika: Explorations in Russian and Eurasian Studies, 14, 2013, 2, pp. 261-96. 
sources that have been made available over the last twenty years and to peer into a world of complex motivations, difficult moral decisions and small pockets of freedom, where others might want to see only one giant edifice of enslavement. 